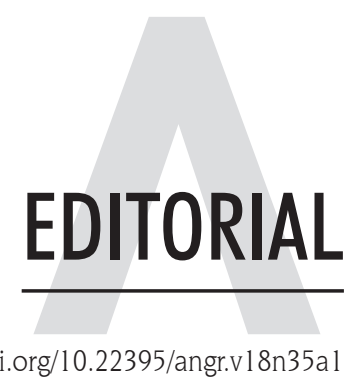

https://doi.org/10.22395/angr.v18n35al

\title{
Los imaginarios urbanos como punto de partida de la ciudadanía
}

Nos convoca la edición número 35 de la revista Anagramas Rumbos y Sentidos de la Comunicación. En esta edición abordamos al ciudadano y sus miradas en las interacciones, redes y conexiones cotidianas. Sea esta la oportunidad de poner sobre el escritorio un debate sobre el ciudadano, lo urbano y los ejes que se entrelazan a través de imaginarios.

Para avanzar en el reconocimiento de la importancia de lo urbano, más allá de las preocupaciones por los elementos sectoriales que lo componen, es importante comprender que la ciudad es un fenómeno sociohistórico propio del dominio del hombre, que tiene un componente espacial particularmente importante. En efecto, el proceso de construcción, modificación y reestructuración del espacio urbano es la instancia que sirve de puente entre el funcionamiento global de la ciudad y la operación particular de cada uno de sus elementos. El análisis y la definición de propuestas de solución para la problemática urbana no se logran satisfactoriamente a través de la sumatoria de saberes especializados. Para el diseño de estrategias y programas es necesario captar la multicausalidad de las relaciones de interdependencia entre cuatro conjuntos de elementos: 1) el suelo, los servicios públicos, la vivienda, el equipamiento, el transporte y el espacio público; 2) las dimensiones política, económica, social, cultural y medioambiental; 3) las instancias de articulación-regulación entre el Estado, las entidades territoriales y la sociedad civil; y 4) el espacio urbano, que se puede expresar en su manifestación sociohistórica para facilitar su asimilación pedagógica en términos físicos y colectivos.

Hablar de la ciudad como institución imaginaria implica concebirla como una creación cultural inmersa en el universo de significaciones que constituyen la sociedad en general y las sociedades específicas en particular. Lo verdaderamente interesante es poder mostrar cómo este universo de significaciones o imaginarios se encaminan lenta pero seguramente, en un momento sociohistórico hacia la construcción de una ciudad. 
Para comprender profundamente lo que es y no es la ciudad, es preciso mostrar en qué sentido es una expresión de lo social. La ciudad es lo que somos todos y lo que no es nadie, lo que jamás está ausente y casi nunca presente como tal, un no-ser más real que todo ser, aquello en lo que estamos sumergidos, pero que jamás podemos aprehender directamente. Es una dimensión indefinida, incluso si se cierra a cada instante; una estructura definida y al mismo tiempo cambiante; una articulación objetivable en categorías de individuos. Es aquello que articula una unidad más allá de todas las diferencias. La ciudad no se puede presentar más que en y por la institución.

La ciudad es una formación muy particular: es una creación de creaciones que configura una forma espacial trabajada, construida y reconstruida a través del tiempo. No es visible como creación acabada y completa, sino que sabemos de ella de una forma fragmentada. La ciudad nunca se abarca en su totalidad como significación imaginaria. Por el contrario, emerge, va saliendo del habitar producido por el hombre en un momento histórico de su desarrollo, en lo más profundo y escondido de su ser. Se manifiesta siempre de manera semioculta, sumergida. Solo sale a la superficie a través de la fragmentación de su existencia: casas, calles, redes de servicio, infraestructuras, arquitecturas, la construcción de espacios materiales y espirituales.

Sobra decir que el interés principal del mundo actual es sobre las apariencias. La moda, el cine, la publicidad, el cuerpo mismo están interesados en las apariencias. Si bien la filosofía platónica giraba en torno a la idea de no fiarse de lo aparente porque es fuente de engaño, el mundo actual se parece entregar por entero a ese «engaño» de las apariencias. El nuestro es un mundo de superficies, y ahí están los medios, según una idea que gana consenso, para ratificar que en las apariencias está lo más parecido, actualmente, al renacimiento del mundo. Si la modernidad desencantó al mundo al explicar desde la racionalidad técnico-científica lo que habían sido los misterios más poéticos desde el principio de los tiempos, la pulsión del instante se convirtió en una manera de vivir cada momento como si en cada uno de ellos se nos fuera la vida. El tiempo actual se caracteriza por una presión constante por vivir cosas nuevas, experimentarlas, dar una suerte de salto al vacío para extasiar al yo moderno enclaustrado rutinariamente en el día a día laboral.

Así, lleno de apariencias, este mundo no es el mismo después de la existencia de Coco Chanel que pensó la indumentaria de la mujer moderna, John Cage que planteó el papel del silencio en la música contemporánea o Maurits Cornelis Escher que, al pintar una mano dibujando otra mano, recodificó la relación entre el espectador y la obra. Todos ellos son creadores de la apariencia que, desde las superficies y los sustratos, han ampliado las fronteras que contienen los límites de la experiencia humana.

Las construcciones del ciudadano están para explicar las dimensiones de lo humano que la razón no alcanza a dominar, esto es, los escenarios de su participación en la ciudad. En este sentido, lo que vivimos hoy con la explosión de imágenes también tiene que ver con la explosión del ciudadano dentro de una ciudad que reinventa superficies significantes que llevan, a través de las pantallas y las redes electrónicas de datos, nuevos mitos del 
cine, el deporte, la moda, el consumo. Estas imágenes están acompañadas de mitos que tienen la apariencia de héroes cinematográficos o marcas. Las imágenes, entonces, le dan existencia a esos nuevos mitos que son las estrellas o celebridades. Pero en ocasiones estos mitos son simplemente mediáticos y no responden con la misma profundidad que los mitos clásicos a los asuntos fundamentales de la vida humana.

Mauricio Andrés Álvarez Moreno

Editor general 